\title{
Production and fermentation characteristics of seafood kimchi started with Leuconostoc mesenteriodes SK-1 isolated from octopus baechu kimchi
}

\author{
Mi-Soon Jang*, Ko-Eun Jung, Jae-Ung Yun, Ki-Ho Nam \\ Food Safety and Processing Research Division, National Institute of Fisheries Science, Busan 46083, Korea
}

\section{문어 배추김치에서 분리한 Leuconostoc mesenteroides SK-1을 이용한 수산물김치의 제조 및 발효 특성}

\author{
장미순*·정고운·윤재웅·남기호 \\ 국립수산과학원 식품위생가공과
}

\begin{abstract}
This study was carried out to investigate the effectiveness of Leuconostoc mesenteroides isolated from octopus baechu kimchi as a potential starter for seafood kimchi. $L$. mesenteroides is lactic acid bacterium currently used as a starter for kimchi production. We selected the most effective $L$. mesenteroides strain from the 7 strains isolated from octopus baechu kimchi and, based on biochemical properties and 16S rRNA sequencing, identified the selected strain as $L$. mesenteroides SK-1. The SK-1 strain exhibited acid-tolerance, good survival capacity, and excellent dextran productivity. We investigated the effects the SK-1 of starter on seafood kimchi fermentation. Octopus baechu kimchi was fermented with $L$. mesenteroides SK-1 at $4^{\circ} \mathrm{C}$ for $35 \mathrm{~d}$. The decrease in $\mathrm{pH}$ and increase in acidity in octopus baechu kimchi fermented with the SK-1 starter occurred more quickly than that in the control kimchi indicating that. Octopus baechu kimchi with SK-1 starter has a relatively slow rate of increase in lactic acid production. As a result, octopus baechu kimchi prepared with $L$. mesenteroides SK-1 can be maintained at a suitable ripening degree over an extended period of time compared to that of the control kimchi, Moreover, the octopus baechu kimchi started with $L$. mesenteroides SK-1 has excellent sensory properties, including a refreshing taste, and a weak sour odor.
\end{abstract}

Key words : octopus baechu kimchi, Leuconostoc mesenteroides, starter, fermentation

\section{서 론}

우리나라 전통 발효 식품인 김치는 배추, 무, 오이 및 깻잎 등 대부분의 채소를 각종 양념에 버무려 만든 식품으 로 그 종류는 약 200여종이다(1). 김치는 밥을 주식으로 하는 한국인의 중요한 부식으로 무기질, 비타민 및 섬유질 이 풍부한 반면 지방 및 단백질 함량이 낮아 저열량 식품으

*Corresponding author. E-mail : suni1@korea.kr Phone : 82-51-720-2651, Fax : 82-51-720-2669

Received 10 October 2016; Revised 24 November 2016; Accepted 25 November 2016.

Copyright (c) The Korean Society of Food Preservation. All rights reserved.
로 알려져 있다. 과거 20여 년 동안 지방질 저하(2), 항동맥 경화(3), 항산화(4), 항당뇨(5), 항암(6), 면역 증가(7), 항염 증(8) 및 항비만(9) 등이 입증되어 우리나라 뿐만 아니라 전 세계적으로 김치의 우수성이 알려짐으로써 단순한 반찬 이 아닌 건강식품으로서의 가치를 인정받고 있다(10).

수산물은 김치를 담글 때 맛을 돋우기 위한 부재료로 사용되어 왔는데, 예로부터 수산물을 사용하여 담근 김치 에 대한 기록이 남아 있다. 1809년 조선시대 빙허각(憑虛閣) 이씨(李氏)가 저술한「규합총서(閨閤叢書)」를 살펴보면, 대구, 민어, 북어, 조기머리와 껍질을 넣고 진하게 달인 육수 를 사용해서 담그는 물김치인 '어육침채', 소라와 낙지를 사용하여 담그는 '섞박지' 및 '전복김치'가 소개되어 있다 (11). 이러한 기록들을 근간으로 해서 현대에는 주로 해안가 
지역을 중심으로 젓갈 외에도 굴, 조기, 명태, 오징어, 새우, 전복 등 다양한 수산물을 첨가한 김치를 담가 먹어 오고 있다. 수산물을 첨가함으로써 김치의 맛 증진뿐만 아니라 아미노산 등 영양가를 보충해 주는 역할을 한다고 알려짐에 따라 김치 부재료로써 수산물에 대한 관심이 증가하였고, 경제성장에 따른 국민소득의 증가로 고급화된 김치에 대한 소비자들의 요구에 의하여 문어, 전복 등을 첨가한 김치가 상품화되고 있다.

일반적으로 시중에서 판매되고 있는 상품김치의 경우, 같은 원료와 방법을 사용하여 제조하여도 김치 발효를 주도 하는 유산균의 종류와 수가 달라지고 숙성 중에는 그 차이 가 더욱 커져 김치의 맛을 일정하게 재현하기가 어렵다는 문제점이 있다. 더욱이, 김치 제조 시 수산물과 같은 동물성 단백질원을 부재료로 첨가하는 수산물김치의 경우 맛이나 품질을 원하는 상태로 일정하게 재현한다는 것은 상당히 어려운 일이다. 최근에 이러한 문제점을 해결하기 위해 김 치에서 유래되는 유산균을 분리하여 김치 제조 시 스타터 (starter)로 첨가함으로써 김치의 맛과 품질을 조절하고 건 강 및 기능적인 특성을 향상시키려는 연구들이 많이 진행되 고 있다. 이러한 연구들로는 김치에서 분리 동정한 Lactobacillus plantarum(KCCM 11352P) 및 Leuconostoc mesenteroides(KCCM 11353P)을 김치 스타터로 단일 및 혼 합 첨가하여 나타나는 항산화 및 항암 효과에 대한 연구(12) 뿐만 아니라 내산성 Leuconostoc mesenteroides 균주와 $\mathrm{GABA}$ (y-Aminobutyric acid)를 첨가하여 맛과 기능성이 향 상된 김치의 제조방법(13), 만니톨 생성능이 우수한 Leuconostoc mesenteroides 동정 분리 연구(14) 및 Leuconostoc citreum 균주를 starter로 접종하여 점질성의 기능성 발효 식품을 제조하는 방법(15) 등의 연구들이 수행되어 있다.

한편, 이와 같은 종래의 연구 보고들은 수산물을 첨가하 지 않고 제조한 김치에서 유래된 유산균인 Leuconostoc속 을 스타터로 활용한 연구들로써, 수산물을 첨가하여 제조 한 김치에 상기 균주를 스타터로 첨가한다 해도, 배합된 원료의 영양성분 및 숙성조건 등의 차이로 인해 미생물의 생육속도가 달라져 수산물김치의 시원하고 신선한 맛을 지속적으로 유지하거나 재현시킬 수 없다는 문제점이 있 다. 따라서 수산물김치의 시원하고 깔끔한 맛을 오랫동안 유지하면서 재현할 수 있는 수산물김치 전용 유산균 스타터 개발이 절실히 요구되는 실정이다. 이에 본 연구에서는 문 어를 첨가하여 제조한 김치로부터 내산성이면서 덱스트란 생성능이 우수한 균주를 분리 · 동정하였으며, 본 균주를 수산물김치의 스타터로서의 활용 가능성을 검토하고자 하 였다.

\section{재료 및 방법}

\section{실험재료}

본 실험에 사용한 문어는 부산 자갈치 시장에서 생물
상태로 구매하여 전 처리한 후 김치 담금에 사용하였다. 배추는 포기당 중량이 $3.0 ~ 3.5 \mathrm{~kg}$ 인 것을 부산 농수산물 시장에서 구매하였고 부재료인 고춧가루(Jonggajip, Gyeonggido, Korea), 까나리액젓(Chungjungone, Seoul, Korea), 새우 젓(Hansung, Chungcheongnam-do, Korea), 설탕(CJ cheilhedang, Seoul, Korea), 천일염(CJ cheilhedang, Seoul, Korea), 다진 마늘, 다진 생강, 실파는 L마트(Busan, Korea)에서 구매하였다.

\section{균주 배양 및 선발}

절인배추 중량 대비 문어를 5 10\%(w/w) 첨가하는 방식 으로 제조한 문어 배추김치를, $4^{\circ} \mathrm{C}$ 에서 25 일간 숙성시키면 서 관능평가를 실시하여 풍미가 가장 좋은 시점의 김치를 유산균 분리 시료로 사용하였다. 문어배추김치는 관능평가 결과 숙성 17 19일 된 것이 가장 맛이 좋은 것으로 평가되었 고, 이 시기의 $\mathrm{pH}$ 가 4.55 , 산도가 $0.65 \%$ 이었다. 상기 문어 배추김치의 김치액즙을 $0.85 \%$ 식염수로 10 배 $(\mathrm{v} / \mathrm{v})$ 희석하 였고, $0.1 \mathrm{~mL}$ 씩 PESA 배지(Phenylethyl alcohol sucrose agar; tryptone $5 \mathrm{~g}$, yeast extract $0.5 \mathrm{~g}$, sucrose $20 \mathrm{~g}$, ammonium sulfate $2 \mathrm{~g}$, magnesium sulfate heptahydrate $0.244 \mathrm{~g}$, potassium phosphate monobasic $1 \mathrm{~g}$, phenylethyl alcohol 2.5 $\mathrm{mL}$, agar $15 \mathrm{~g} / \mathrm{DW} 1 \mathrm{~L}$ ) 플레이트에 접종한 후, 유리막대로 도말하였다. 이후, 플레이트를 $20^{\circ} \mathrm{C}$ 의 항온 배양기 (DE/BD-BED115, Binder, NY, USA)에서 5일 동안 배양하 였다. 생성된 각각의 콜로니(colony) 중 우점균으로 분리된 유산균 콜로니 7종(SK1 SK7)을 선택하였고, 내산성 및 덱 스트란 활성능이 뛰어난 균주를 선발하여 실험에 사용하였 다. 비교균주로서 김치 유래의 Leuconostoc mesenteroides $\mathrm{KCTC} 13302$ 와 덱스트란 생성능이 우수한 것으로 알려진 Leuconostoc mesenteroides KCTC3505(Korean Collection for Type Culture, Daejeon, Korea)을 미생물자원센터에서 분양받아 사용하였다.

\section{균주의 내산성 및 덱스트란 생성량 측정}

균주의 내산성 측정을 위해 젖산으로 $\mathrm{pH}$ 를 $3.2,3.5,4.0$, 4.5 및 5.0으로 조정한 $\mathrm{PES}$ 배지 $10 \mathrm{~mL}$ 에 위에서 우점균으로 분리한 유산균 콜로니 7종과 비교균주로 사용한 $\mathrm{KCTC}$ 13302 및 KCTC3505 2종의 균체배양액 각각 $1 \mathrm{~mL}$ 씩 접종 하여 $20^{\circ} \mathrm{C}$ 에서 72 시간 배양하면서 생육유무를 관찰하였다.

덱스트란 생성량을 측정하기 위해, 유산균 콜로니 7종과 비교균주 2종을 PES 배지 $10 \mathrm{~mL}$ 에 2 차에 걸쳐 계대배양을 실시하였다. 이후, 유산균 콜로니 7종 및 비교균주 2종을 $\mathrm{PES}$ 배지 $100 \mathrm{~mL}$ 에 $1 \%(\mathrm{v} / \mathrm{v})$ 로 각각 접종하여 $20^{\circ} \mathrm{C}$ 에서 5 일 동안 배양한 후 각각의 배양액 $50 \mathrm{~mL}$ 를 채취하여 10 분 동안 $1.887 \times \mathrm{g}$ 로 원심분리하여 맑은 상층액을 얻었다. 상층 액에 10 배의 에탄올을 첨가하여 침전된 덱스트란을 회수하 고 동결건조를 실시하여 건조된 덱스트란의 양을 측정하였 다(16). 


\section{균주 동정}

형태학적 특성을 분석하기 위해 유산균을 최적 조건에서 배양하여 그람염색(gram staining)과 카탈라제(catalase) 실 험을 실시하였다. 선발한 유산균 균주의 생화학적 특성 검 사를 위해 API-50CH(BioMerieux, Marcy l'Etoile, France)를 사용하여 탄소원 이용패턴을 조사하였고, 유산균 균주의 동정은 $16 \mathrm{~S} \mathrm{rDNA}$ 염기서열의 상동성을 분석하였다. 즉, $16 \mathrm{~S}$ DNA 염기서열을 결정하기 위해 일반적인 방법에 따라 정제된 $\mathrm{DNA}$ 를 주형으로 하여 $\mathrm{PCR}$ 로 증폭하였다. 증폭된 DNA단편을 Big Dye Terminator Cycle Sequencing kit(Applied Biosystems, Waltham, MA, USA)로 정제한 다 음, DNA sequencer(Applied Biosystems model 3730XL)를 이용하여 염기서열을 결정하였다. 결정된 염기서열을 EzTaxon server 2.1을 이용하여 상동성을 분석하였다.

\section{스타터 배양액 및 문어 배추김치의 제조}

선발된 유산균 균주를 $\mathrm{PES}$ 배지에 접종한 후 $20^{\circ} \mathrm{C}$ 에서 24 시간 동안 1 차 배양하였고, 1 차 배양액을 PES 배지에 $1 \%(\mathrm{v} / \mathrm{v})$ 접종한 후 $20^{\circ} \mathrm{C}$ 에서 24 시간동안 2 차 배양을 실시하 였다. 2 차 배양액을 멸균된 $\mathrm{PES}$ 배지에 $1 \%$ 접종한 후 $20^{\circ} \mathrm{C}$ 에서 24시간동안 배양하는 단계를 거쳐 스타터 배양액을 제조하였다. 스타터 배양액은 $1,207 \times \mathrm{g}$ 에서 10 분간 원심분 리하여 하층의 균체를 회수하는 과정을 거친 뒤, 멸균 생리 식염수 $(0.85 \% \mathrm{NaCl})$ 에 $1 \times 10^{7 \sim 8} \mathrm{CFU} / \mathrm{mL}$ 되게 희석하여 사 용하였다.

김치에 첨가하기 위해 문어의 내장을 제거하고 깨끗이 세척하여 물기를 뺀 후 문어 전체 중량 대비 $3 \%(\mathrm{w} / \mathrm{w})$ 의 천일염을 넣고 버무린 것을 $4^{\circ} \mathrm{C}$ 의 냉장고에서 24 시간 저장 한 다음 흐르는 물에 여러 번 세척하여 짠맛을 제거시킨 후 감초 물에 3 5분간 데친 것을 사용하였다. 배추는 이물 질을 제거하고 이등분하여 뿌리부분에 $4 \sim 6 \mathrm{~cm}$ 칼집을 넣은 후, 줄기 쪽 위주로 배추무게의 $3 \%(\mathrm{w} / \mathrm{w})$ 가 되게 천일염을 뿌렸으며, 천일염으로 만든 $10 \%$ 염수를 배추 총 중량의 2 배가 되게 침지시켜 약 $18^{\circ} \mathrm{C}$ 에서 12 시간 이상 절인 후, 배추의 염도가 $1.8 \pm 0.1 \%$ 에 도달하였을 때 흐르는 물에 2회 세척하여 채반에 건져 4시간 탈수하였다.

스타터 배양액을 첨가한 문어 배추김치의 제조를 위해 절인배추 $(78.3 \%)$ 와 고춧가루(2.35\%), 마늘( $2.35 \%)$, 까나리 액젓 $(1.17 \%)$, 새우젓 $(1.57 \%)$, 생강 $(0.47 \%)$, 찹쌀풀(3.38\%), 설탕 $(0.47 \%)$, 양파 $(2.11 \%)$ 를 혼합한 김치 양념, 그리고 전 처리 한 문어는 적당한 크기로 썰어 절인 배추 중량의 $10 \%$ $(\mathrm{w} / \mathrm{v})$ 가 되도록 첨가하였다. 스타터 배양액은 김치양념 전 체 중량 대비 $3 \%(\mathrm{w} / \mathrm{v})$ 가 되도록 첨가하여 혼합하였다. 문어 는 스타터 배양액이 혼합되어 있는 김치 양념과 같이 버무 려 배추 속에 넣어 문어 배추김치를 제조하였고, 이와 같은 방법으로 제조한 문어 배추김치의 최종 염도는 $2.2 \pm 0.1 \%$ 이 었다. 스타터 배양액을 첨가하지 않은 문어 배추김치를 대
조구로 설정하였으며 비교균주로서 사용한 $L$ mesenteroides KCTC13302 및 L. mesenteroides KCTC3505 균주 배양액을 스타터로서 첨가하여 담근 문어 배추김치를 양성대조군으 로 하였다. 모든 시료는 $4{ }^{\circ} \mathrm{C}$ 의 냉장 조건에서 35 일 동안 보관하며 7일 간격으로 실험에 사용하였다.

\section{$\mathrm{pH}$ 및 산도 측정}

문어와 배추의 비율이 $1: 9(\mathrm{~g} / \mathrm{g})$ 의 비율이 되도록 시료를 취하고 잘게 다진 후 거즈로 짠 액을 $\mathrm{pH}$ 와 산도 실험에 사용하였다. $\mathrm{pH}$ 는 $\mathrm{pH}$ meter(Orion 3 Star, Thermo Fisher Scientific, Waltham, MA, USA)를 사용하여 측정하였고, 산 도는 시험용액 $10 \mathrm{~mL}$ 에 $\mathrm{pH}$ meter 전극을 담그고 $0.1 \mathrm{~N}$ $\mathrm{NaOH}$ 로 $\mathrm{pH}$ 가 8.1이 될 때까지 적정하여 중화시키는데 소 요된 $\mathrm{NaOH}$ 용량 $(\mathrm{mL})$ 을 lactic acid로 환산하여 총산 함량 (\%)으로 표시하였다(17).

\section{젖산 생성량 측정}

위에서 제조한 스타터 첨가 문어 배추김치와 대조구로서 스타터 무첨가 김치를 대상으로 젖산 생성량을 측정하여 비교하였다. 젖산 생성량은 HPLC(US/Acquity UPLC H-Class, Waters, Milford, MA, USA)를 이용한 유기산 분석법에 의거 하여 측정하였다. 문어 배추김치 각 시료의 김치액즙을 $12,754 \times \mathrm{g}$ 에서 10 분간 원심 분리하여 얻은 상층액을 0.22 $\mu \mathrm{m}$ syringe filter로 여과하였다. 여과된 시료는 HPLC를 이 용하여 시료 $10 \mu \mathrm{L}$ 를 주입하였고 이동상 $8 \mathrm{mM} \mathrm{H}_{2} \mathrm{SO}_{4}$ 를 사용하여 분당 $0.6 \mathrm{~mL}$ 로 흐르게 설정하였다. 이때 사용한 칼럼은 Aminex HPX-87H $(300 \times 7.8 \mathrm{~mm}, 9 \mu \mathrm{m}$, Bio-rad, Hercules, CA, USA)이었고 칼럼온도는 $35^{\circ} \mathrm{C}$ 로 하여 분석 하였다.

\section{Leuconostoc sp. 균수의 측정}

Leuconostoc sp. 균수를 측정하기 위해, $4^{\circ} \mathrm{C}$ 에서 35 일 동 안 숙성시킨 각 김치시료 즙액을 $0.85 \%$ 식염수로 희석하여 $10^{-7}$ 의 김치 희석액을 제조하였고, 상기 김치 희석액 0.1 $\mathrm{mL}$ 씩을 Leuconostoc 선택배지로 phenylethyl alcohol과 sucrose를 첨가한 PES medium에 접종한 후 유리막대로 도 말하였다. 김치 희석액이 도말된 Leuconostoc sp. 측정 agar plate는 $20^{\circ} \mathrm{C}$ 의 항온 배양기에서 5 일 동안 배양하여 생성된 콜로니의 수를 각각의 균수로 계수하였다.

\section{관능평가}

관능평가는 국립수산과학원의 10 명의 훈련된 관능검사 원(25 30세, 남, 여 각 5 명)을 대상으로 실시하였고 각각의 김치 시료를 $20 \mathrm{~g}$ 씩 접시에 담아 검사원에게 제공하였다. 관능검사는 9점 척도법(18)에 따라 종합적인 맛, 탄산미, 시원한 맛, 깔끔한 맛 및 신 냄새는 객관적인 평가에 의해 각 김치의 특성을 강도(매우 강하다, 9점; 보통이다, 5 점; 
매우 약하다, 1점)로 평가하였으며, 외관, 조직감 및 종합적 기호는 선호도(매우 좋다, 9점; 보통이다, 5점; 매우 싫다, 1점)로 평가하였다.

\section{결과 및 고찰}

\section{수산물 김치용 종균 선정}

수산물 김치용 종균은 균주의 내산성 및 덱스트란 생성 의 결과를 바탕으로 선정하였다. 문어 배추김치로부터 우 점종으로 분리된 7종의 유산균 콜로니(SK1 SK7)와 비교 균주 2종 $(L$. mesenteroides KCTC13302, L mesenteroides KCTC3505)의 내산성을 비교한 결과를 Table 1에 나타내었

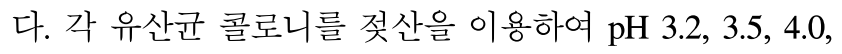
4.5 및 5.0 으로 조정한 $\mathrm{PES}$ 배지에 접종한 후 생육유무를 관찰한 결과, 콜로니 SK-1, SK-2, SK-5 및 비교균주 $\mathrm{KCTC} 13302$ 와 $\mathrm{KCTC} 3505$ 가 $\mathrm{pH}$ 3.5 5.0에서 활발하였고, 특히 $\mathrm{pH} 3.2$ 에서도 SK-1균주는 생육하여 내산성이 강한 것으로 나타났다.

Table 1. Acid tolerance of lactic acid bacteria isolated from octopus baechu kimchi

\begin{tabular}{cccccccc}
\hline \multirow{2}{*}{ Strains } & & \multicolumn{5}{c}{$\mathrm{pH}$} \\
\cline { 2 - 7 } & & 3.2 & 3.5 & 4.0 & 4.5 & 5.0 \\
\hline & SK-1 & + & + & + & + & + \\
& SK-2 & - & + & + & + & + \\
Colonies selected from octopus & SK-3 & - & - & + & + & + \\
added kimchi & SK-4 & - & - & + & + & + \\
& SK-5 & - & + & + & + & + \\
& SK-6 & - & - & + & + & + \\
& SK-7 & - & - & + & + & + \\
\hline L. mesenteroides KCTC13302 & - & + & + & + & + \\
L. mesenteroides KCTC3505 & & - & + & + & + & + \\
\hline
\end{tabular}

문어 배추김치로부터 내산성 유산균 콜로니로 선별된 SK-1, SK-2, SK-5 및 비교균주 KCTC13302와 KCTC3505를 대상으로 덱스트란 생성량을 측정하여 Fig. 1에 나타내었 다. SK-1, SK-2 및 SK-3 유산균 콜로니의 덱스트란 생성량 을 측정한 결과 각각 $4.5 \%, 2.2 \%$ 및 $3.4 \%$ 를 나타내어 SK- 1 균주가 가장 많은 덱스트란을 생성함을 알 수 있었다. 한편, 비교균주인 $\mathrm{KCTC} 13302$ 와 $\mathrm{KCTC} 3505$ 는 각각 $3.5 \%$ 및 $3.9 \%$ 를 나타내었고, SK-1 균주의 덱스트란 생성량을 비교 해 보면, KCTC13302 균주보다는 덱스트란 생성량이 약 $22 \%$ 정도 높게 나타났고, 덱스트란 생성능이 우수하다고 알려진 KCTC3505 균주보다는 약 13\%정도 많은 덱스트린 을 생성하였다.

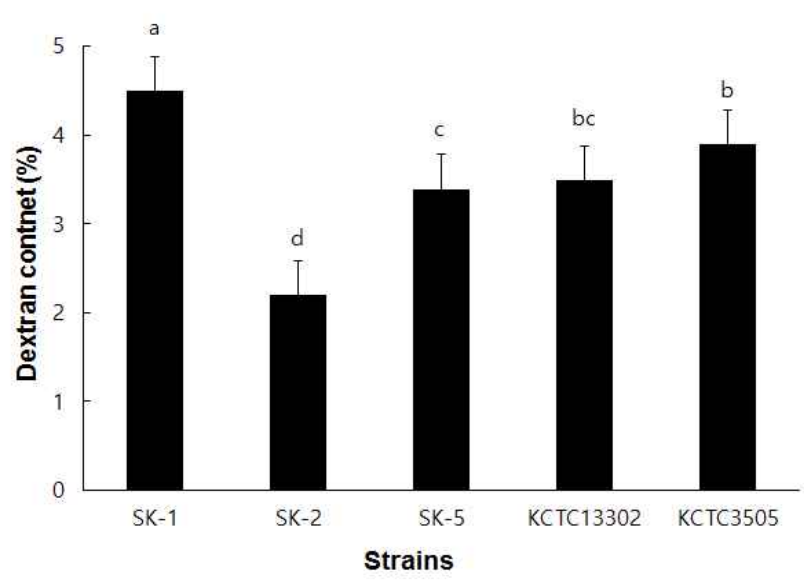

Fig. 1. Distribution of dextran producing lactic acid bacteria isolated from octopus baechu kimchi.

Values are mean $\pm \mathrm{SD}(\mathrm{n}=3)$.

${ }^{a-d}$ Different letters on bars indicate significant differences $(\mathrm{p}<0.05)$.

이상의 결과에서 문어 배추김치로 분리한 SK-1균주는 내산성이면서 덱스트란 생성능이 우수함을 알 수 있었다. 이 SK-1 균주의 형태학적 특성 분석을 위해, 그람염색을 실시한 결과 그람 양성으로 간균의 형태를 나타내었고, catalase 실험에서는 음성반응을 보여 Leuconostoc sp.의 형 태적 특징과 일치하였다.

또한, SK-1 균주를 대상으로 API-50CH를 사용하여 49종 의 탄수화물 발효 패턴을 확인한 결과, L-arabinose, ribose, D-xylose, D-glucose, D-fructose, methyl-a,D-glucoside, $\mathrm{N}$-acethyl-glucosamine, maltose, melibiose, sucrose, trehalose, D-raffinose 및 D-turanose를 이용하는 것으로 나타났다 (Table 2). 이 결과를 ATB 동정 컴퓨터 시스템에 입력하고 동정한 결과 탄수화물 발효 패턴이 $L$ mesenteroides에 속하는 균주인 것으로 판명되었다. 한편, SK-1 균주의 $16 \mathrm{~S} \mathrm{rDNA}$ 염기서열 분석하여 상동성을 조사한 결과, L mesenteroides 의 염기서열과 $99 \%$ 동일함에 따라 분리한 SK-1균주를 $L$. mesenteroides SK-1으로 명명하고 이를 수산물 김치용 종균 으로 사용하였다.

$\mathrm{pH}$ 와 산도의 변화

$\mathrm{pH}$ 및 산도는 미생물과 상관관계에 있으며 특히 산도는 김치의 품질을 결정하는 지표라고 한다(19). L mesenteroides SK-1 균주 첨가, 균주 무첨가 및 비교균주 첨가 김치의 $\mathrm{pH}$ 및 산도 변화는 fig. 2 및 3에 나타내었다.

Fig. 2에 나타낸 것처럼, 숙성 14 일째까지는 Leuconostoc sp. 균주를 첨가하지 않은 음성 대조군의 문어 배추김치가 비교 균주 첨가 김치 및 L. mesenteroides SK-1 균주 김치보 다 높은 $\mathrm{pH}$ 값을 나타내었다. 그러나, 숙성 21 일 이후부터는 L.mesenteroides SK-1 균주 배양액을 첨가한 문어 배추김치 의 $\mathrm{pH}$ 가 4.56에 도달하면서 이후 계속 유지되는 양상을 보인 반면, L. mesenteroides KCTC3505 및 KCTC13302를 
Table 2. Carbohydrate utilization pattern of the strain SK-1 isolated from octopus baechu kimchi

\begin{tabular}{|c|c|c|c|}
\hline Carbohydrate & Activity & Carbohydrate & Activity \\
\hline Glycerol & - & Esculine & - \\
\hline Erythritol & - & Salicin & - \\
\hline D-Arabinose & - & Celobiose & - \\
\hline L-Arabinose & + & Maltose & + \\
\hline Ribose & + & Lactose & - \\
\hline D-Xylose & + & Melibiose & + \\
\hline L-Xylose & - & Sucrose & + \\
\hline Adonitol & - & Trehalose & + \\
\hline B-Methyl-D-xyloside & - & Inulin & - \\
\hline Galactose & - & Melezitose & - \\
\hline D-Glucose & + & D-raffinose & + \\
\hline D-Fructose & + & Starch & - \\
\hline D-Manose & - & Glycogen & - \\
\hline L-Sorbose & - & Xylitol & - \\
\hline Rhamnose & - & $\beta$-gentiobiose & - \\
\hline Dulcitol & - & D-turanose & + \\
\hline Inositol & - & D-lyxose & - \\
\hline Manitol & - & D-tagatose & - \\
\hline Sorbitol & - & L-fucose & - \\
\hline a-Methyl-D-manoside & - & D-arabitol & - \\
\hline a-Methyl-D-glucoside & + & L-arabitol & - \\
\hline N-Acethyl glucosamine & + & Gluconate & - \\
\hline Amygdaline & - & 2-keto-gluconate & - \\
\hline Arbutin & - & 5-keto-gluconate & - \\
\hline
\end{tabular}

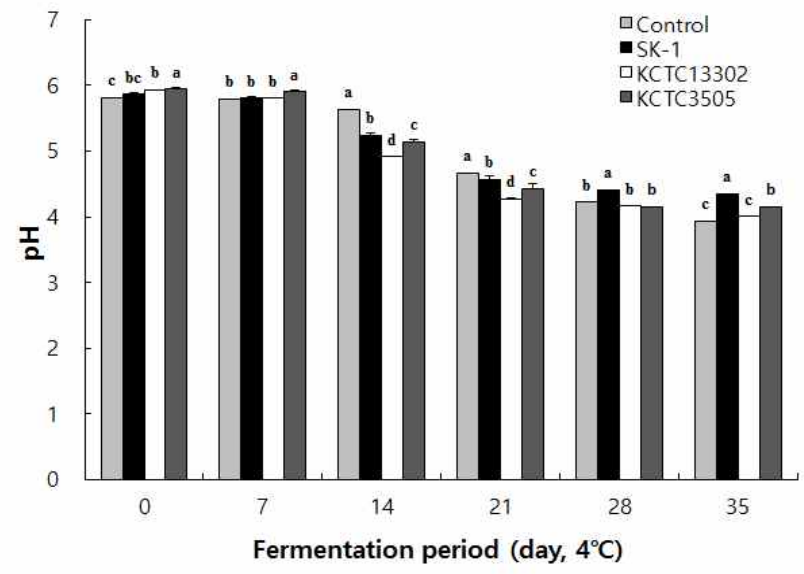

Fig. 2. Changes in $\mathrm{pH}$ of octopus baechu kimchi with various strains during fermentation for 35 days at $4^{\circ} \mathrm{C}$.

Values are mean $\pm \mathrm{SD}(\mathrm{n}=3)$.

Control, Octopus baechu kimchi without strains; SK-1, Octopus baechu kimchi with Leuconostoc mesenteroides SK-1; KCTC3505, Octopus baechu kimchi with Leuconostoc mesenteroides KCTC3505; KCTC13302, Octopus baechu kimchi with Leuconostoc mesenteroides KCTC13302.

${ }^{a-d}$ Different letters on bars indicate significant differences $(p<0.05)$
첨가한 양성 대조군의 문어 배추김치와 Leuconostoc sp. 균주를 미첨가한 음성 대조구의 문어 배추김치는 숙성 21 일 이후부터 $\mathrm{pH}$ 값이 감소하는 경향을 나타내었다.

L. mesenteroides SK-1 균주 첨가 김치의 산도 변화는 $4^{\circ} \mathrm{C}$ 에서 숙성 28 일째 적정 산도 $0.65 \%$ 에 도달하였으나, L. mesenteroides KCTC3505 및 KCTC13302 균주를 첨가한 김치는 각각 숙성 21 일 및 17 일경에 적정 숙성 산도인 $0.65 \%$ 에 도달하는 것으로 나타났다. 또한, L. mesenteroides SK-1 균주를 이용하여 제조한 문어 배추김치는 숙성 35일 째에도 산도가 $0.8 \%$ 에 도달하지 않았으나, Leuconostoc sp. 균주를 첨가하지 않은 음성대조구의 문어 배추김치를 비롯 하여 L. mesenteroides KCTC3505 및 KCTC13302 균주를 첨가한 양성 대조군의 문어 배추김치는 저장 28 일째부터 산도가 $0.8 \%$ 에 도달하였고 이후부터는 급속하게 산도 값이 증가하는 양상을 나타내었다.

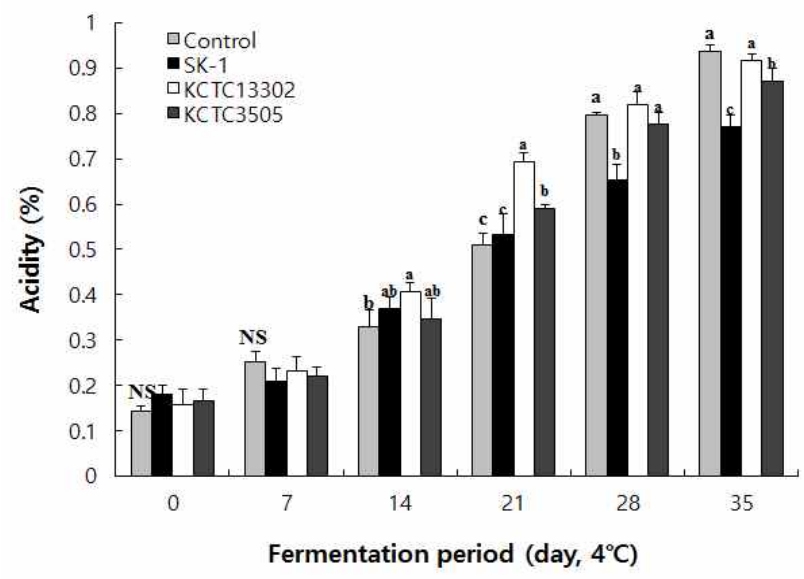

Fig. 3. Changes in acidity of octopus baechu kimchi with various strains during fermentation for 35 days at $4^{\circ} \mathrm{C}$.

Values are mean \pm SD $(n=3)$.

Control, Octopus baechu kimchi without strains; SK-1, Octopus baechu kimchi with Leuconostoc mesenteroides SK-1; KCTC3505, Octopus baechu kimchi with Leuconostoc mesenteroides KCTC3505; KCTC13302, Octopus baechu kimchi with Leuconostoc mesenteroides KCTC13302.

${ }_{a-0}$ Different letters on bars indicate significant differences $(p<0.05)$

${ }^{\mathrm{NS}}$ Data are not significantly different.

\section{젖산 생성량의 변화}

L. mesenteroides SK-1 균주 배양액을 스타터로서 첨가하 여 제조한 문어 배추김치와 대조군으로 사용된 문어 배추김 치를 대상으로 젖산 생성량을 측정한 결과를 Fig. 4에 나타 내었다. L. mesenteroides SK-1 균주 배양액을 스타터로 이 용하여 제조한 문어 배추김치는 숙성 21 일째 젖산 생성량 이 $0.72 \mathrm{mg} / \mathrm{mL}$ 를 나타낸 이후 숙성 28 일 및 35 일째에도 젖산 생성량은 $0.76 \mathrm{mg} / \mathrm{mL}$ 및 $0.79 \mathrm{mg} / \mathrm{mL}$ 로 일정한 값을 유지한 반면에, 음성대조구로서 Leuconostoc sp. 균주를 미첨 가한 문어 배추김치와 L. mesenteroides $\mathrm{KCTC} 3505$ 및 $\mathrm{KCTC} 13302$ 균주를 첨가한 양성대조군의 문어 배추김치는 숙성 28 일째에 젓산생성량이 각각 $0.96 \mathrm{mg} / \mathrm{mL}, 1.15 \mathrm{mg} / \mathrm{mL}$ 
및 $1.12 \mathrm{mg} / \mathrm{mL}$ 로 급속히 젖산 생성량이 증가하는 경향을 나타내었다.

이상의 결과를 종합하면 문어 배추김치에서 분리· 동정 된 L mesenteroides SK-1 균주를 이용하여 문어 배추김치와 같이 수산물을 첨가하는 김치를 제조하게 되면, 일반 배추 김치에서 분리 - 동정된 Leuconostoc sp. 균주를 이용한 것 보다도 수산물김치의 적정 $\mathrm{pH}$ 및 산도를 유지하는 기간이 길어지고 젖산 생성을 적게 함으로서 수산물김치의 장기간 유통 및 저장이 가능할 것으로 기대되었다.

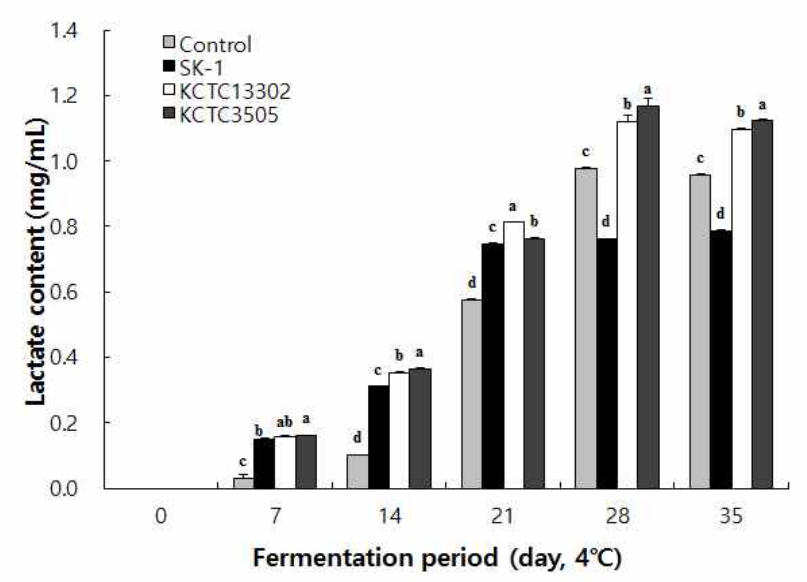

Fig. 4. Changes in lactic acid contents of octopus baechu kimchi with various strains during fermentation for 35 days at $4^{\circ} \mathrm{C}$.

Values are mean \pm SD $(n=3)$.

Control, Octopus baechu kimchi without strains; SK-1, Octopus baechu kimchi with Leuconostoc mesenteroides SK-1; KCTC3505, Octopus baechu kimchi with Leuconostoc mesenteroides KCTC3505; KCTC13302, Octopus baechu kimchi with Leuconostoc mesenteroides KCTC13302.

${ }^{a-d}$ Different letters on bars indicate significant difference $(p<0.05)$.

\section{Leuconostoc sp. 균수의 변화}

김치 발효는 주로 혐기적으로 각종 효소 및 미생물의 번식으로 김치 속의 주요 성분들이 분해 및 합성을 거치며 진행된다(19). 발효 초기에는 주로 $L$ mesenteroides가 증식하 며 이는 발효를 주도하는 균으로 다른 유산균에 비해 생육 이 빠르고 젖산, 초산 및 $\mathrm{CO}_{2}$ 를 생성하여 탄산미를 부여하 여 김치의 맛과 냄새에 좋은 영향을 준다고 알려져 있다. 중기에는 동형 발효 유산균이 Lactobacillus plantarum이, 말기에는 이형 발효 유산균인 Lactobacillus brevis가 작용하 여 발효를 진행시킨다(20). L mesenteroides SK-1 균주 첨가 문어 배추김치 및 균주 무첨가 문어 배추김치를 대상으로 Leuconostoc sp. 균수의 변화를 Fig. 5에 나타내었다. 숙성 35 일의 기간 동안에 $L$. mesenteroides SK-1 및 $L$. mesenteroides KCTC3505 및 KCTC13302 균주를 첨가한 양 성 대조군의 문어 배추김치는, Leuconostoc sp. 균주를 미첨 가한 음성대조구의 문어 배추김치에 비해 Leuconostoc sp. 균주의 수가 현저히 높게 나타났다. 또한, L mesenteroides SK-1 균주를 이용하여 제조한 문어 배추김치는 $4{ }^{\circ} \mathrm{C}$ 에서
숙성 14 일째 이후부터 Leuconostoc sp. 균수가 $10^{8} \mathrm{CFU} / \mathrm{mL}$ 이상의 수준으로 일정하게 유지되는 것으로부터, 첨가한 L. mesenteroides SK-1 균주가 문어 배추김치 내에서 우점종 으로 발효를 주도하여 문어 배추김치의 시원한 맛을 지속적 으로 유지시킬 수 있음을 확인할 수 있었다.

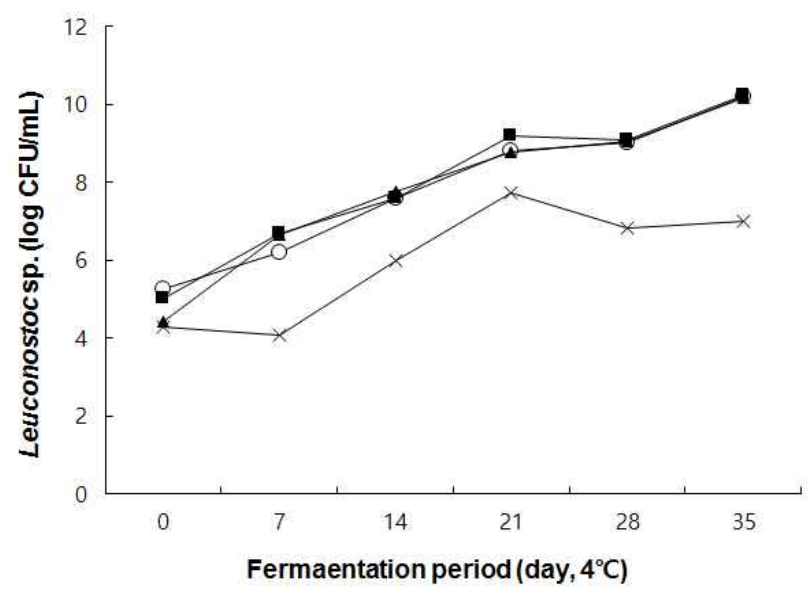

Fig. 5. Change in lactic acid bacteria viable cell counts of octopus baechu kimchi with various strains during fermentation for 35 days at $4^{\circ} \mathrm{C}$.

$\times$, Control (octopus baechu kimchi without strains); $\bigcirc$, Octopus baechu kimchi with Leuconostoc mesenteroides SK-1; $\mathbf{\square}$, Octopus baechu kimchi with Leuconostoc mesenteroides KCTC3505; $\mathbf{\Lambda}$, Octopus baechu kimchi with Leuconostoc mesenteroides KCTC13302.

관능평가

각종 균주를 첨가한 김치가 $4^{\circ} \mathrm{C}$ 에서 숙성 28 일째 되었을 때 관능적 특성을 조사하기 위해 객관적인 평가와 선호도평 가로 실시하였다(Table 3). 객관적 평가 항목에서는 종합적 인 맛, 탄산미, 시원한 맛 및 깔끔한 맛 부분에서 SK-1 균주 첨가 김치군이 각 $7.6,7.2,7.1$ 및 7.1 점으로 다른 김치 군들에 비해 유의적으로 가장 점수가 높게 나타났으며, 신 냄새에서는 5.1점으로 균주 미첨가 군(7.2점), $\mathrm{KCTC} 3505$ (6.3점) 및 $\mathrm{KCTC} 13302$ (5.8점) 균주 첨가군들에 비해 유의 적으로 가장 낮은 점수를 나타내었다(p<0.05). 균주 미첨가 김치군이 냄새에서 유의적으로 가장 높은 점수를 나타내 고, 나머지 항목에서 가장 낮은 평가를 받은 결과를 살펴보 았을 때, 김치에 유산균을 첨가하는 것이 김치의 관능적인 부분에 긍정적인 효과를 나타냄을 알 수 있었다. 또한 선호 도 평가에서도 마찬가지로 SK-1 균주 첨가 김치 군이 외관 에서 7.1점, 조직감 7.0점 및 종합적 기호도 7.1점으로 다른 군들에 비해 외관(6.3 4.8점), 조직감(6.4 4.3), 종합적 기호 도(6.3 4.7)의 모든 항목에서 유의적으로 높은 점수를 나타 내었다 $(\mathrm{p}<0.05)$. 이러한 결과는 저온살균 절인 배추에 starter 첨가한 연구(21), starter 첨가가 김치의 발효에 미치 는 효과 연구(22) 및 김치 미생물 조성을 바탕으로 한 김치 스타터의 선정 및 효과 연구(23)들과 유사하게 나타내었다. 
Table 3. Sensory intensity results of octopus baechu kimchi with various strains

\begin{tabular}{ccccc}
\hline & \multicolumn{4}{c}{ Samples $^{1)}$} \\
\cline { 2 - 5 } & Control & SK-1 & KCTC3505 & KCTC13302 \\
\hline Overall taste & $\left.4.70 \pm 0.82^{\mathrm{c} 2}\right)$ & $7.60 \pm 0.70^{\mathrm{a}}$ & $5.00 \pm 0.82^{\mathrm{c}}$ & $6.60 \pm 0.97^{\mathrm{b}}$ \\
Carbonated taste & $4.70 \pm 0.82^{\mathrm{c}}$ & $7.20 \pm 0.78^{\mathrm{a}}$ & $5.00 \pm 0.66^{\mathrm{c}}$ & $6.01 \pm 0.73^{\mathrm{b}}$ \\
Refreshing taste & $5.30 \pm 0.67^{\mathrm{c}}$ & $7.10 \pm 0.73^{\mathrm{a}}$ & $6.20 \pm 0.79^{\mathrm{b}}$ & $6.50 \pm 0.71^{\mathrm{ab}}$ \\
Clean taste & $4.60 \pm 0.84^{\mathrm{c}}$ & $7.10 \pm 0.98^{\mathrm{a}}$ & $6.30 \pm 0.82^{\mathrm{b}}$ & $5.30 \pm 0.67^{\mathrm{c}}$ \\
Sour odor & $7.20 \pm 0.78^{\mathrm{a}}$ & $5.10 \pm 0.73^{\mathrm{c}}$ & $6.30 \pm 0.82^{\mathrm{b}}$ & $5.80 \pm 0.91^{\mathrm{bc}}$ \\
Appearance & $4.80 \pm 0.79^{\mathrm{c}}$ & $7.10 \pm 1.10^{\mathrm{a}}$ & $6.30 \pm 0.84^{\mathrm{ab}}$ & $5.60 \pm 1.30^{\mathrm{bc}}$ \\
Texture & $4.30 \pm 0.95^{\mathrm{c}}$ & $7.00 \pm 0.81^{\mathrm{a}}$ & $6.40 \pm 0.70^{\mathrm{a}}$ & $5.40 \pm 0.70^{\mathrm{b}}$ \\
Overall acceptability & $4.70 \pm 0.82^{\mathrm{b}}$ & $7.10 \pm 0.99^{\mathrm{a}}$ & $6.30 \pm 0.82^{\mathrm{a}}$ & $5.20 \pm 1.03^{\mathrm{b}}$ \\
\hline
\end{tabular}

${ }^{1)}$ Control, Octopus baechu kimchi without strains; SK-1, Octopus baechu kimchi with Leuconostoc mesenteroides SK-1; KCTC3505, Octopus baechu kimchi with Leuconostoc mesenteroides KCTC3505; KCTC13302, Octopus baechu kimchi with Leuconostoc mesenteroides KCTC13302.

${ }^{2) a-c}$ Different letters within the same row indicate significant difference $(\mathrm{p}<0.05)$.

\section{요 약}

본 연구에서는 수산물김치의 시원한 맛과 풍미를 오랫동 안 유지시켜 줄 수 있는 수산물김치 전용 유산균 스타터를 찾고자 하였다. 문어 배추김치로부터 내산성 및 덱스트란 생성능이 우수한 균주 SK-1을 선발하고 동정한 결과 $L$. mesneteriodes와 $99 \%$ 상동성을 나타내어 L. mesneteriodes SK-1으로 명명하였다. 수산물김치 스타터로서 $L$. mesneteriodes SK-1 균주의 활용가능성을 알아보기 위해, $\mathrm{pH}$, 산도, 젖산 생성량 및 Lesuconostoc sp. 균주의 변화를 L. mesneteriodes KCTC 13302 및 L. mesneteriodes KCTC 3505 균주와 비교하였다. L. mesneteriodes SK-1 균주 배양 액을 스타터로서 첨가하여 제조한 문어 배추김치의 $\mathrm{pH}$ 는 숙성 21 일 이후부터는 4.56 에 도달한 이후 계속 유지되는 양상을 보인 반면 L. mesneteriodes KCTC 13302 및 KCTC 3505 배양액을 첨가한 문어 배추김치는 숙성 21일 이후부 터 $\mathrm{pH}$ 가 감소하는 경향을 나타내었다. 또한, L mesneteriodes SK-1 균주를 첨가한 문어 배추김치의 산도는 $4^{\circ} \mathrm{C}$ 에서 숙성 28 일째 적정 산도 $0.65 \%$ 에 도달한 반면에 L. mesneteriodes KCTC 13302 및 KCTC 3505 균주를 첨가한 문어 배추김치 는 각각 숙성 17 일 및 21 일 경에 적정 숙성 산도인 $0.65 \%$ 에 도달하였다. 또한, L. mesneteriodes SK-1 균주를 첨가한 문어 배추김치는 숙성 21 일째 젖산 생성량이 $0.72 \mathrm{mg} / \mathrm{mL}$ 를 나타낸 이후 숙성 28 일 및 35 일째에도 젖산 생성량은 0.76 $\mathrm{mg} / \mathrm{mL}$ 및 $0.79 \mathrm{mg} / \mathrm{mL}$ 로 일정한 값을 나타내었으나, $L$. mesneteriodes KCTC 13302 및 KCTC 3505 균주를 첨가한 문어 배추김치는 숙성 28 일째에 젖산생성량이 급속히 증가 하여 각각 $1.12 \mathrm{mg} / \mathrm{mL}$ 및 $1.15 \mathrm{mg} / \mathrm{mL}$ 을 나타내었다. 한편, L. mesneteriodes SK-1 균주를 첨가한 문어 배추김치는 숙성
14 일째 이후부터 Leuconostoc sp. 균수가 $10^{8} \mathrm{CFU} / \mathrm{mL}$ 이상 의 수준을 일정하게 유지되는 결과를 나타내었고 관능평가 결과에서도 SK-1 균주를 첨가한 김치가 KCTC 13302 및 $\mathrm{KCTC} 3505$ 균주를 첨가한 김치보다도 신맛은 적고 시원한 맛, 탄산미 등의 종합적인 맛 평가에서 유의적으로 높은 점수를 받았다. 이상의 결과로부터 L. mesneteriodes SK-1 균주를 첨가하여 제조한 수산물김치는 산도 및 젖산생성량 이 낮아 적정 숙성도가 오래 유지됨으로서 관능적으로도 우수할 뿐만 아니라 장기간 저장 및 유통이 가능한 수산물 김치 전용 스타터로서의 활용가능성이 기대되었다.

\section{감사의 글}

본 논문은 2016년도 국립수산과학원 수산과학연구사업 청소년의 수산물 소비 확대를 위한 맞춤형 식품가공 기술 개발(R2016063)의 지원에 의해 운영되었습니다.

\section{References}

1. Yoon SS (1991) A Historical study of Korean traditional kimchi. Korean J Dietary Culture, 6, 467-477

2. Kwon MJ, Song YO, Song YS (1997) Effects of kimchi on tissue and fecal lipid composition and apolipoprotein and thyroxine levels in rats. J Korean Soc Food Sci Nutr, 26, 507-513

3. Kim HJ, Lee JS, Chung HY, Song SH, Sun H, Noh JS, Song YO (2007) 3-(4'-Hydroxyl-3',5'-dimethoxyphenyl) propionic acid, an active principle of kimchi, inhibits development of atherosclerosis in rabbits. J Agric Food Chem, 55, 10486-10492

4. Lee YM, Kwon MJ, Kim JK, Suh HS, Choi JS, Song YO (2004) Isolation and identification of active principle in Chinese cabbage kimchi responsible for antioxidant effect. Korean J Food Sci Technol, 36, 129-133

5. Islam MS, Choi H (2009) Antidiabetic effect of Korean traditional Baechu (Chinese cabbage) kimchi in a type 2 diabetes model of rats. J Med Food, 12, 292-297

6. Shin KS, Chae OH, Park IC, Hong SI, Choe TB (1998) Antitumor effects of mice fed with cell lysates of lactobacillus plantarum isolated from kimchi. Korean J Biotechnol Bioengin, 13, 357-363

7. Kim MJ, Kwon MJ, Song YO, Lee EK, Youn HJ, Song YS (1997) The effects of kimchi on hematological and immunological parameters in vivo and in vitro. J Korean Soc Food Sci Nutr, 26, 1-7 
8. Noh JS, Choi YH, Song YO (2013) Beneficial effects of the active principle component of Korean cabbage kimchi via increasing nitric oxide production and suppressing inflammation in the aorta of apoE knockout mice. Br J Nutr, 109, 17-24

9. Kim EK, An SY, Lee MS, Kim TH, Lee HK, Hwang WS, Choe SJ, Kim TY, Han SJ, Kim HJ, Kim DJ, Lee KW (2011) Fermented kimchi reduces body weight and improves metabolic parameters in overweight and obese patients. Nutr Res, 31, $436-443$

10. Lee JJ, Jeong YK (1999) Cholesterol-lowering effect and anticancer activity of kimchi and kimchi ingredients. Korean J Life Sci, 9, 743-752

11. Jang MS, Park HY, Nam KH (2012) Changes in nutrient composition and fermentation properties of Abalone Mul-kimchi using dried pollack and Licorice stock. Korean J Food Sci Technol, 44, 613-620

12. Bong YJ, Jeong JK, Park KY (2013) Fermentation properties and increased health punctionality of kimchi by kimchi lactic acid bacteria starters. J Korean Soc Food Sci Nutr, 42, 1717-1726

13. Oh JY, Lee JH, Heo BS, Go EC (2005) Acid tolerant Leuconostoc mesenteroides isolated from Kimchi and method for producing a tasty Kimchi using the same. Korea Patent No. 0536108

14. Oh JY, Yang SY, Kwon MS, Lee JH, Han GH, Go EC (2008) Acid tolerant Leuconostoc mesenteroides with excelllent mannitol productivity and method for producing a kimchi using the same. Korea Patent No. 0077390

15. Lee SB, Lee IS, Son MJ (2007) Functional fermented food produced by using Leuconostoc citreum isolated from kimchi and phellinus linteus and a method of preparing thereof. Korea Patent No. 0718344
16. Kim JE, Whang K, Lee SP (2012) Physicochemical properties of dextran produced by Leuconostoc mesenteroides SM according to concentration of yeast extract and its modulation of rheological properties. Korean J Food Sci Technol, 44, 216-223

17. Lee HY, Paik JE, Han YS (2003) Effect of powder- type dried Alaska pollack addition on the quality of kimchi. Korean J Soc Food Cookery Sci, 19, 254-262

18. Ku HS, Noh JS, Yoon YR, Kim HJ, Kwon MJ, Cheigh HS, Song YO (2007) Weight reduction and lipid lowering effects of sea tangle added Korean cabbage kimchi. J Korean Soc Food Sci Nutr, 36, 1140-1147

19. Kim DA, Ahn BW, Yeum DM, Lee DH, Kim SB, Park YH (1987) Depredation carcinogenic nitrosamine formation factor by natural food components-1. Nitrite scavenging effects of vegetable extracts. Bull Korean Fish Soc, 20, 463-468

20. Sung JM, Choi HY (2009) Effects of Alaska pollack addition on the quality of kimchi (Korean salted cabbage). Korean J Food Preserv, 16, 772-781

21. Han GJ, Choi HS, Lee SM, Lee EJ, Park SE, Park KY (2011) Addition of starters in pasteurized brined Baechu cabbage increased kimchi quality and health functionality. J Korean Soc Food Sci Nutr, 40, 110-115

22. Lee SH, Kim SD (1988) Effect of starter on the fermentation of kimchi. J Korean Soc Food Nutr, 17, 342-347

23. Jin HS, Kim JB, Yun YJ, Lee KJ (2008) Selection of kimchi starters based on the microbial composition of kimchi and their effects. J Korean Soc Food Sci Nutr, 37, 671-675 